\title{
Correspondence
}

CHINA \& WTO ReV. 2019:2; 411-416

http://dx.doi.org/10.14330/cwr.2019.5.2.07

pISSN $2383-8221 \cdot$ elSSN $2384-4388$

China and WTO Review

\section{The Influence of Sino-US Summit on Trade Negotiation: An Analysis of the 2019 G20 in Osaka}

\author{
Yingying $\mathrm{Wu}^{*}$
}

This article analyzes the Sino-US Summit in Osaka in 2019 and its influence on trade negotiations between China and the US in the near future. By a look at the reports from China's side and the US' side, the article figures out what has been agreed and what are the most controversial issues on table. Having an observation of the new development after the Summit, the article tries to analyze the direction and ways forwards for the Sino-US trade talks, and make predictions based on a certain of factors including challenges faced by the US, the need of China as well as the attitude of the world. It is easy to figure out that agricultural products and the supply of equipment relating to Huawei were the key points at issue in the Sino-US Summit as well as in the future. The exchange and compromises are necessary between China and the US regardless of whether they are happy to admit it or not.

Keywords: Sino-US Summit, G20 Osaka, Huawei, Trade War, Tariffs

\section{Overview}

The Group of 20 meeting was held in Osaka on June 28-29, 2019. On the side line of this meeting, President Xi Jinping and President Trump had the SinoUS Summit on June 29. Other members of G20 and all over the world draw great attention to this 80 minutes' talks in light of trade war between China and

* Lecturer, School of International Law at China University of Political Science and Law. J.S.D.(U. Illinois at Urbana-Champaign), LL.M.(NYU). She may be contacted at: wyyfada@163.com. All the websites cited in this article were last visited on August 10, 2019. 
the US. Steven Mnuchin, the US Ministry of Department of the Treasury even overestimated that the possibility of concluding a trade agreement or memorandum was as high as 90 percent in the Sino-US Summit in Osaka. ${ }^{1}$ Both parties and other countries looked forward to this meeting with great expectation since last April's trade talk between China and the US failed to come to any significant result.

\section{Reports from China}

Right after the Sino-US Summit, China's side reported: both President Xi and President Trump agreed to restart trade negotiations on the basis of mutual respect and the principle of equality; the US would not impose new tariffs on imports from China with the expectation that China would increase imports from the US; and Details would be discussed further by trade negotiators from both sides. ${ }^{2}$ Given that the rest of exports from China to the US is some USD 300 billion, the US would not impose new tariffs in the short term. The possibility for China to retaliate is also lowered accordingly. The trade disputes between China and the US is not likely to be escalated in the short term. ${ }^{3}$

\section{Reports from the US}

The Sino-US Summit was an important meeting for President Trump, as well. He twitted on the day right after the Summit that the US would not impose any new tariffs on Chinese exports, while the talks were underway, and that China had agreed to resume broad purchases of American farm products and other goods. Trump finally announced the resumption of stalled trade talks with China. In addition, Mr. Trump said that "US companies can sell their equipment to Huawei," and hence backtracked on a ban on sales of American equipment to Huawei, the Chinese telecom giant. ${ }^{4}$

It is reported that President Trump and President Xi promised to made concessions. However, the extent of easing the ban is not clear in terms of that on supplying equipment (equipment of double usage without impact on national security) to Huawei and other Chinese enterprises, and whether Huawei would be removed from the blacklist. It is not clear about the amount of agricultural products that China promised to buy from the US. ${ }^{5}$ 


\section{New development after the Summit}

After the Summit, the US announced that it would exempt 110 items from increased tariffs, indicating the willingness to supply equipment to Chinese enterprises instead of economic sanctions and bans. ${ }^{6}$ Some American companies have applied the permits to the US Department of Commerce to export equipment to Chinese enterprises, including Huawei. Nevertheless, it is not clear how many permits and licenses will be issued in the future. Any incidents and turbulence will affect the issuance of these permits and licenses.

Recently, the US exports millions of tons of beans to China. In particular, Chinese enterprises started to offer to buy beans, cotton, pork, wheat, and other agricultural products from the American farmers in July. As some of these offers have been processed, Chinese enterprises have applied for exemption of increased tariffs on these agricultural products. ${ }^{7}$ These applications would be dealt with the Committee on Tariffs and Rules within the State Council of China.

However, President Trump announced on August 8, 2019 that the US would impose 10 percent tariffs on imports of some USD 300 billion from China starting from September 1, 2019. This is a backlash from the outcome of the Sino-US Summit. China responded that it is against the outcome of the Osaka Summit, and that China is ready for retaliation. ${ }^{8}$

\section{Future Forwards}

The Sino-US Summit does not necessarily have significant influence on Chinese trade negotiation policy against the US tariffs. Nevertheless, trade negotiations were restarted which indicates the willingness of both sides to come back to the track. It is not surprising that the matter of Huawei arose in the Summit, although the ease of the ban all of a sudden is out of expectation, given that President Trump is self-regarded as "a great trader," and China is leveraging against the farmers in the US, who are the primary voters for the Republican Party where Trump belongs to. ${ }^{9}$

It is easy to figure out that agricultural products and the supply of equipment relating to Huawei were the key points at issue in the Sino-US Summit as well as in the future. The exchange and compromises are necessary between China 
and the US regardless of whether they are happy to admit it or not. Considering the US Presidential Election 2020, on the one hand, President Trump is faced with the pressure from the agricultural sector which demands to export more agricultural products to China. On the other hand, China is faced with the pressure of equipment supplies due to US' ban on exports of high techniques to China as shown at the Huawei case.

The trade war between China and the US has affected not only both nations, but also interested countries and individuals. For instance, European countries are getting more passive in exports and investment in China. ${ }^{10}$

Trade accords will contribute to the stable investment worldwide. It is not clear whether retaliatory tariffs will be imposed again if trade talks between China and the US stalks once again, in particularly when recalling that the previous rounds of trade talks were at deadlock over the past year. Nevertheless, the possibility is not lowered by the promise from the Sino-US Summit. President Trump's personal character and his businessman style make everything uncertain. ${ }^{11}$ Trade disputes represent the current situation that the two nations are competing for the world leader position. ${ }^{12}$ The future trade negotiations will largely depend on the extent of compromise both sides are willing to make.

\section{REFERENCES}

1. C. Hughes, Treasury Chief Mnuchin: US-China Trade Deal 90 percent Done, UPI, June 26, 2019, available at https:/www.upi.com/Top_News/World-News/2019/06/26/Treasurychief-Mnuchin-US-China-trade-deal-90-percent-done/2721561546170.

2. Xi Jinping and Trump Had A Meeting, and Both Side Agreed to Restart Trade Negotiations [习近平与特朗普进行会晤 中美元首同意重启两国经贸碰商], Time WeEKLY.COM [时代周报], June 29, 2019, available at $\mathrm{http}: / / \mathrm{www}$. sohu.com/a/323839881_237556.

3. Ming Zhang, An Analysis of Outcomes of the G20 Osaka Summit [张明: G20大阪峰会中美 会谈的结果分析], CAIXIN [财新], June 30, 2019, available at http://opinion.caixin.com/201906-30/101433343.html.

4. 5 Takeaways from the G20 Summit: Easing off Trump's China Trade War, for Now, N.Y. Times, June 29, 2019, available at https:/www.nytimes.com/2019/06/29/world/asia/g20summit-takeaways.html.

5. Zak Doffman, Huawei Welcomes Trump 'U-Turn' on US Supplier Ban after Xi Meeting at 
G20, June 29, 2019, ForbES, available at HTTPS://wWw.FORBES.COM/SITES/ZAKDOFFMAN/ 2019/06/29/TRUMP-SIGNALS-HUAWEI-BLACKLIST-CONCESSION-AFTER-XI-TALKS-THEY-CAN-BUYFROM-U-S/\#F0ED35520A1C.

6. Development Had Been Made Regarding Purchasing Agricultural Goods from the US by Chinese Enterprises [近期中国企业采购美国农产品取得进展], XINHUANEWs, July 28, 2019, available at http://www.xinhuanet.com/politics/2019-07/28/c_1210218636.htm.

7. Id.

8. See Chinese Response to US' Plan to Impose 10\% Tariffs on Chinese Products of About \$ 300 Billion [美方拟对 3000 亿美元中国输美商品加征 $10 \%$ 关税！中方回应], PeOPLE's DAILY [人 民日报], Aug. 9, 2019, available at https://baijiahao.baidu.com/s?id=164138540022477803 $9 \& w f r=$ spider $\&$ for $=$ pc.

9. Yuhan, Ninglian \& Renshen, China and the US Restart Trade Negotiations after G20, and Huawei Was Released by Trump [G20中美重启贸易谈判 特朗普一句话解禁华为?], DW.COM, available at https://www.dw.com/zh/g20中美重启贸易谈判-特朗普一句话解禁华 为 $/ \mathrm{a}-49410296$.

10. Id.

11. Id.

12. Id. 
